\title{
Diversity of mites in blackberry genotypes in Pelotas, Rio Grande do Sul, Brazil
}

\author{
Claudia Teresita Olmedo Trinidad ${ }^{1 *}$ João Pedro Fagundes ${ }^{2}$ Bruno Zorzo $^{2}$ \\ Dori Edson Nava $^{3}$ Uemerson Silva da Cunha ${ }^{2}$ iD
}

\begin{abstract}
${ }^{1}$ Programa de Pós-graduação em Fitossanidade, Departamento de Fitossanidade (DFs), Faculdade de Agronomia Eliseu Maciel (FAEM), Universidade Federal de Pelotas (UFPel), Campus Universitário, 96160-000, Pelotas, RS, Brasil. E-mail: clauolmedo09@gmail.com. "Corresponding author.

${ }^{2}$ Departamento de Fitossanidade (DFs), Faculdade de Agronomia Eliseu Maciel (FAEM), Universidade Federal de Pelotas (UFPel), Pelotas, RS, Brasil.

${ }^{3}$ Empresa Brasileira de Pesquisa Agropecuária, Embrapa Clima Temperado, Pelotas, RS, Brasil.

ABSTRACT: Blackberry is part of the small-fruit group and the blackberry cultivation area is expanding as an important option for small farmers using the agroecological production system. Mites are prominent among the world's major crop pests, as they can affect plants from growth to fruiting. The objective of this study was to evaluate the occurrence of phytophagous and predatory mites in different blackberry genotypes in the municipality of Pelotas, RS, Brazil. This study was carried out in the period Nov. 2015 - Oct. 2016, totaling 14 samples. A total of 11,158 mites were collected [phytophagous (5940) and predatory (323) mites, and those with varied feeding habits (4895)], which were distributed in 8 families. The species Neotetranychus asper (Feres \& Flechtmann, 2000), Diptacus rubuscolum (Trinidad, Duarte \& Navia, 2018), and Acalitus orthomerus (Keifer, 1951) had highest occurrence. According to the faunistic classification, the N. asper phytophagous species is predominant in genotypes 128 and 178; whereas, D. rubuscolum is predominant in genotype 132. Monitoring of these genotypes is recommended to detect possible damage to the crop.

Key words: Rubus spp., faunistic analysis, phytophagous, predators.
\end{abstract}

Diversidade de ácaros em genótipos de amoreira-preta em Pelotas, Rio Grande do Sul

RESUMO: A amoreira-preta faz parte do grupo das pequenas frutas e sua área de cultivo está em plena expansão, sendo uma opção importante para os pequenos agricultores que usam o sistema de produção agroecológico. Os ácaros destacam-se dentre as principais pragas da cultura em nivel mundial, pois eles podem comprometer desde o crescimento das plantas até sua frutificação. O objetivo desta pesquisa foi estudar a ocorrência de ácaros fitófagos e predadores em diferentes genótipos de amoreira preta no municipio de Pelotas, RS, Brasil. Este estudo foi realizado no periodo novembro de 2015 a outubro de 2016, totalizando 14 amostragens. Um total de 11.158 ácaros coletou-se (5.940 ácaros fitófagos, 323 ácaros predadores, e 4.895 ácaros de alimentação variada), que estavam distribuídos em oito familias. As espécies Neotetranychus asper (Feres \& Flechtmann, 2000), Diptacus rubuscolum (Trinidad, Duarte \& Navia, 2018), e Acalitus orthomerus (Keifer, 1951) tiveram maior ocorrência. De acordo com a classificação faunistica, a espécie fitófaga N. asper é predominante nos genótipos 128 e 178, enquanto a espécie D. rubuscolum é predominante no genótipo 132. Monitorar esses genótipos é recomendado para detectar possiveis danos à cultura.

Palavras-chave: Rubus spp., diversidade, fitófagos, predador.

\section{INTRODUCTION}

Cultivation of the blackberry tree (Rubus spp., Rosaceae) is expanding in Brazil, and it has been used in an agroecological production system (ANTUNES et al., 2010) due to its great adaptability, low installation cost, and management. In Brazil, its cultivation began in the 1970 s, with development in the breeding program (RASEIRA \& FRANZON, 2012). The cultivars currently used in Brazil are the result of crosses of the native and
North-American genetic material (ANTUNES et al., 2014).

Blackberry is subject to a considerable number of pests, such as with other crops, and they can affect the blackberry tree by affecting its production (PAGOT et al., 2007). Currently, pest management in Brazil is restricted and based only on working knowledge, since research-generated information is lacking (NAVA et al., 2007). Blackberry weevil (Eulechriops rubi) and fruit fly (Anastrepha spp.) were cited as the main pests in Brazil (NAVA et 
al., 2007; ANTUNES et al., 2014). In addition, the presence of mites has already been reported in Brazil, specifically in Rio Grande do Sul State (MARCHETTI \& FERLA, 2011). However, specific studies are necessary to obtain information about the predominant mite species, their potential for harm, and how they could become a threat to commercial systems for blackberry production, as it has occurred with Acalitus essigi Hassan, 1928 (KEIFER et al., 1982; BAKER et al., 1996; DAVIES et al., 2001a, PINA et al., 2012) or Acalitus orthomerus (Keifer, 1951) (BAKER et al., 1996) in other countries.

Species of phytoseiids, eriophids, tarsonemids, tetranychids, and thideids were reported in association with blackberry cultivars (MARCHETTI \& FERLA, 2011; MCMURTRY \& SHOW, 2012). According to MCMURTRY \& SHOW (2012), a low diversity of phytoseiid mites has been observed in commercial blackberry trees, and this may be related to intensive cultivation practices, such as lack of plant diversity, alternative foods, and adverse effects of spraying with pesticides. However, six species of mites of the family Phytoseiidae reported in blackberry trees were reported in Portugal as follows: [Neoseiulus californicus (McGregor, 1954), Amblyseius graminis Chant, 1956, Euseius stipulatus (Athias-Henriot, 1960), Neoseiulella perforata (Athias-Henriot, 1960), and Typhlodromus (Anthoseius) recki Wainstein, 1958], and a species of the family Stigmaeidae. The stigmaeid Agistemus longisetus Gonzalez, 1963 and phytoseiid E. stipulatus and $N$. californicus (PINA et al., 2012) mites were the most common of those predators.

The study conducted by MARCHETTI \& FERLA (2011) on blackberry cultivars (Brazo, Caingangue, and Tupy) in the municipality of Ilópolis (RS) showed that the occurrence of phytophagous mites of the families Diptilomiopidae and Tetranychidae was predominant and those of the Tenuipalpidae family was smaller in number. Among predatory mites, the families Stigmaeidae (Agistemus brasiliensis Matioli, Ueckermann \& Oliveira, 2002) was the most abundant species) and Phytoseiidae (Typhlodromalus aripo (DeLeon, 1967) was the most prevalent species in the Caingangue cultivar) were outstanding.

Given this scenario, knowledge about mite diversity in various blackberry genotypes in the southern region of RS will provide additional information to further studies in other regions of this state. This knowledge, along with subsequent studies on Biology and Ecology of mites, will contribute to the management of potential pests in the crop. Therefore, the objective of this study was to determine the fauna of mites in blackberry genotypes in the southern region of Rio Grande do Sul.

\section{MATERIALS AND METHODS}

This study was carried out in the period Nov. 2015 - Oct. 2016 in an experimental orchard of Embrapa Clima Temperado (latitude $31^{\circ} 42^{\prime} \mathrm{S}$, longitude $52^{\circ} 24^{\prime} \mathrm{O}$, and altitude de $57 \mathrm{~m}$ ), in the municipality of Pelotas, RS, Brazil. Blackberry genotypes 128, 132, 139, 164, 178, 181, and 198 and "Tupy" were used. All plants were arranged in parallel lines $(50 \mathrm{~cm}$ between plants and $3 \mathrm{~m}$ between rows), without support system, except those of Tupy cultivar, which were supported by two wire strands and driven approximately in $V$. Five plants (replicates) per genotype were evaluated. In each crop and in the period of experimentation, the plants were kept without agrotoxic application and the cultural treatments were carried out according to the technical recommendations for the crop.

Samples were collected monthly from November to October, except in November and December (fruiting months), when they were collected biweekly (total: 14 samplings). Six leaflets (two in each of the upper, middle and lower thirds) were collected from each plant (total: 240 leaflets per sample). In the flowering and fruiting period, two flowers and four fruits (both from the upper and middle third) were collected per repetition, and 10 samples were collected per genotype (total: 80 flowers and 160 fruits) per collection season. Samples were placed in paper bags and packed in styrofoam boxes to be transported to the Acarology Laboratory (Federal University of Pelotas), where they were processed (under a Nikon SMZ 745 stereomicroscope, with the help of brushes and tweezers). Mites were identified in the same laboratory using a phase-contrast (Nikon E200) microscope.

In the laboratory, the leaves were observed (on the adaxial and abaxial surface) under a stereomicroscope, when the mites were collected and quantified. Regarding Eriophyoidea, mites were quantified in $1 \mathrm{~cm}^{2}$ area of the leaf (on the abaxial surface) by which it is united with the petiole. Fruits were evaluated in only half the sample, examining the regions between drupes and counting the number of specimens. Specimens collected from leaves, flowers, and fruits were transferred to Eppendorf flasks containing $70 \%$ alcohol solution. Then, they were mounted on slides containing Hoyer's medium, remaining in an oven $\left(50^{\circ} \mathrm{C} ; 10-15\right.$ days $)$, and adult mites were then identified and quantified. 
The morphological characters observed on both surfaces of the leaves were described from samples of different parts of the plants. The presence or absence of acule and domatia (GONÇALVES \& LORENZI, 2007) and trichomes and types of tricoma and indument (BEENTJE, 2016) were evaluated according to the literature. Leaf trichome densities were evaluated by comparing genotypes. This morphological description was performed at the Botanical Laboratory (Embrapa Clima Temperado).

Results were analyzed using the AnaFau software (MORAES et al., 2003). The faunistic indexes for dominance, abundance, frequency, constancy, and Shannon-Wiener diversity ( $\left.\mathrm{H}^{\prime}\right)$ were calculated to characterize the mite fauna in different blackberry genotypes.

\section{RESULTS AND DISCUSSION}

The occurrence of 12 species of mites distributed in eight families was recorded (Table 1), totaling 11,158 mites classified as phytophagous (5940), predatory (323), and miscellaneous-feeding (4895) mites. In analyzing mite distribution per family, the Tydeidae, Diptilomiopidae, Tetranychidae, and Eriophyidae families showed a higher representability. The predominance of certain mite families may be associated with their preference for the host plant, favoring their establishment and development. In addition, the presence of the tetranychid Neotetranychus asper (Feres \& Flechtmann, 2000) and tydeid Tydeus californicus (Banks, 1904) was observed in all plant genotypes. Conversely, the eriophyoid Diptacus rubuscolum (Trinidad, Duarte \& Navia, 2018) showed a relatively-high population in all plant genotypes in the months of November, December, and January of 2016; although, this species has only been described recently by TRINIDAD et al. (2018). However, the eriophid Acalitus orthomerus (Keifer, 1951) occurred in drupes in greater quantity in Dec. 2015 and Jan. 2016, when fruits reach maturation and are harvested; although, it has not been sampled in leaves, floral buds, or open flowers. This has led to a drastic reduction in mite population, which is also related to the significant seasonal changes in host plant morphology (DAVIES et al., 2001b) and it is good if the decrease in the number of mites in the plant is considered.

Table 1 - Mite species present in blackberry genotypes. Pelotas, RS.

\begin{tabular}{|c|c|c|}
\hline \multirow[t]{2}{*}{ Families/Species } & \multicolumn{2}{|c|}{-------------Individuals---------- } \\
\hline & $(\mathrm{N})$ & $\%$ \\
\hline \multicolumn{3}{|l|}{ Tetranychidae } \\
\hline Neotetranychus asper (Feres \&Flechtmann, 2002) & 1638 & 14.68 \\
\hline Oligonychus yothersi(McGregor, 1915) & 211 & 1.89 \\
\hline \multicolumn{3}{|l|}{ Diptilomiopidae } \\
\hline Diptacus rubuscolum(Trinidad, Duarte \& Navia, 2018) & 1864 & 16.71 \\
\hline \multicolumn{3}{|l|}{ Eriophyidae } \\
\hline Acalitus orthomerus (Keifer, 1951) & 1204 & 10.79 \\
\hline \multicolumn{3}{|l|}{ Tarsonemidae } \\
\hline Polyphagotarsonemus latus (Banks, 1904) & 1005 & 9 \\
\hline \multicolumn{3}{|l|}{ Tenuipalpidae } \\
\hline Brevipalpus spp. (Donnadieu, 1875) & 18 & 0.16 \\
\hline \multicolumn{3}{|l|}{ Stigmaeidae } \\
\hline Agistemus spp. (Sumers, 1960) & 167 & 1.50 \\
\hline \multicolumn{3}{|l|}{ Tydeidae } \\
\hline Tydeus californicus(Banks, 1904) & 4895 & 43.87 \\
\hline \multicolumn{3}{|l|}{ Phytoseiidae } \\
\hline Euseius mesembrinus (Dean,1957) & 33 & 0.30 \\
\hline Amblyseius operculatus (DeLeon 1967) & 5 & 0.04 \\
\hline Galendromus (Galendromus) annectens (De Leon, 1958) & 10 & 0.09 \\
\hline Typhlodromalus aripo (DeLeon, 1967) & 108 & 0.97 \\
\hline Total & 11,158 & 100 \\
\hline
\end{tabular}


Significant differences were observed between the number of mites in each genotype evaluated (Table 2). The $N$. asper had a similar frequency in the plant genotypes 139, 164, 181, and 198 and "Tupy". However, genotype 164 and "Tupy" were the most favorable for the tetranychid mite Oligonychus yothersi (McGregor, 1915). Diptacus rubuscolum, Polyphagotarsonemus latus (Banks, 1904), and Brevipalpus spp. (Donnadieu, 1875) showed no significant difference in the evaluated genotypes and "Tupy". Acalitus orthomerus had a similar occurrence in all genotypes (except genotype 128) and "Tupy". Tydeus californicus occurred similarly in genotypes 132, 139, 164, 178, and 198 and "Tupy". Few mites Euseius mesembrinus (Dean, 1957) were found mostly in genotype 128 and "Tupy". Phytoseiid mites Amblyseius operculatus (De Leon, 1967), Galendromus (Galendromus) annectens (De Leon, 1958), and Typhlodromalus aripo (De Leon, 1967) did not differ in the number of individuals in each genotype and "Tupy".

Regarding the number of occurrences, $N$. asper, D. rubuscolum, and T. californicus showed similar amounts in genotypes 128 and 164 (Table 2). In genotype 132 , the observed number of $D$. rubuscolum and T. californicus was similar. Tydeus californicus showed difference in relation to other mite species reported in genotypes 139 and 178. Genotype 181 showed no difference in the number of $N$. asper, D. rubuscolum, A. orthomerus, P. latus, Agistemus spp., and T. californicus. Occurrence of $N$. asper, D. rubuscolum, A. orthomerus, and T. californicus did not differ in the number of individuals in genotype 198 and "Tupy".

According to the faunal analysis (Tables 3 and 4), variation in mite distribution and behavior was observed in various genotypes. This may be related to the differences between genotypes regarding morphological characters on the adaxial surface of the leaf (Table 5). In genotypes 128 and 178, N. asper, D. rubuscolum, and T. californicus were considered prevailing, as they reached the maximum rates in faunal classification (Tables 3 and 4). For genotype 128 , only the E. mesembrinus predatory mite showed to be dominant, very abundant, very frequent, and constant. This may suggest that the complex of phytoseiid mites found in the present study was not sufficient to regulate the number of these species of pest mites.

The same species was also reported by MARCHETTI \& FERLA (2011) and occurred in Brazos and Tupy cultivars. Mites of the genus Euseius are classified as generalist predators, for which pollen is an important part of the diet, increasing their reproductive potential after flowering (MCMURTRY et al., 2013).

Typhlodromalus aripo was another phytoseiid that reached high values for abundance and frequency rates in genotype 178. This species was reported in the Caingangue blackberry cultivar

Table 2 - Average number of mites per plant collected in blackberry orchard in the period Nov 2015 - Oct. 2016, in the municipality of Pelotas, RS.

\begin{tabular}{|c|c|c|c|c|c|c|c|c|}
\hline \multirow[t]{2}{*}{ Mite species } & \multicolumn{8}{|c|}{ - } \\
\hline & 128 & 132 & 139 & 164 & 178 & 181 & 198 & Tupy \\
\hline Neotetranychus asper & $24^{\mathrm{bcABC}}$ & $5^{\mathrm{dBC}}$ & $33^{\mathrm{abB}}$ & $110^{\mathrm{aA}}$ & $8^{\mathrm{cdBC}}$ & $33^{\mathrm{abA}}$ & $73^{\mathrm{aAB}}$ & $52^{\mathrm{abA}}$ \\
\hline Oligonychus yothersi & $2^{\mathrm{bCD}}$ & $0^{\mathrm{bC}}$ & $0^{\mathrm{bC}}$ & $22^{\mathrm{aBC}}$ & $1^{\mathrm{bDE}}$ & $1^{\mathrm{bC}}$ & $1^{\mathrm{bCD}}$ & $15^{\mathrm{aB}}$ \\
\hline Diptacus rubuscolum & $84^{\mathrm{aA}}$ & $66^{\mathrm{aA}}$ & $41^{\mathrm{aB}}$ & $38^{\mathrm{aAB}}$ & $32^{\mathrm{aB}}$ & $29^{\mathrm{aA}}$ & $48^{\mathrm{aAB}}$ & $17^{\mathrm{aAB}}$ \\
\hline Acalitus orthomerus & $7^{\mathrm{bBCD}}$ & $11^{\mathrm{abB}}$ & $7^{\mathrm{aB}}$ & $31^{\mathrm{abBC}}$ & $19^{\mathrm{abBC}}$ & $24^{\mathrm{abAB}}$ & $43^{\mathrm{abAB}}$ & $63^{\mathrm{aA}}$ \\
\hline Polyphagotarsonemus latus & $2^{\mathrm{aBCD}}$ & $4^{\mathrm{aBC}}$ & $57^{\mathrm{aC}}$ & $1^{\mathrm{aD}}$ & $0^{\mathrm{aE}}$ & $49^{\mathrm{aAB}}$ & $137^{\mathrm{aBC}}$ & $0^{\mathrm{aD}}$ \\
\hline Brevipalpus sp. & $1^{\mathrm{aCD}}$ & $0^{\mathrm{aC}}$ & $0^{\mathrm{aC}}$ & $2^{\mathrm{aD}}$ & $0^{\mathrm{aE}}$ & $0^{\mathrm{aC}}$ & $1^{\mathrm{aCD}}$ & $0^{\mathrm{aD}}$ \\
\hline Agistemus spp. & $2^{\mathrm{bCD}}$ & $2^{\mathrm{bBC}}$ & $2^{\mathrm{abC}}$ & $8^{\mathrm{abCD}}$ & $2^{\mathrm{abDE}}$ & $7^{\mathrm{abAB}}$ & $2^{\mathrm{abCD}}$ & $10^{\mathrm{aBC}}$ \\
\hline Tydeus californicus & $58^{\mathrm{bcAB}}$ & $98^{\mathrm{abA}}$ & $258^{\mathrm{aA}}$ & $143^{\mathrm{abA}}$ & $247^{\mathrm{aA}}$ & $21^{\mathrm{cAB}}$ & $113^{\mathrm{abA}}$ & $68^{\mathrm{abA}}$ \\
\hline Euseius brazili & $4^{\mathrm{aABCD}}$ & $0^{\mathrm{bC}}$ & $1^{\mathrm{bC}}$ & $0^{\mathrm{bD}}$ & $1^{\mathrm{bDE}}$ & $0^{\mathrm{bC}}$ & $0^{\mathrm{bD}}$ & $2^{\mathrm{abD}}$ \\
\hline Amblyseius operculatus & $0^{\mathrm{aD}}$ & $0^{\mathrm{aC}}$ & $0^{\mathrm{aC}}$ & $0^{\mathrm{aD}}$ & $0^{\mathrm{aE}}$ & $1^{\mathrm{aC}}$ & $0^{\mathrm{aD}}$ & $0^{\mathrm{aD}}$ \\
\hline Galendromus (G.) annectens & $0^{\mathrm{aD}}$ & $0^{\mathrm{aC}}$ & $0^{\mathrm{aC}}$ & $1^{\mathrm{aD}}$ & $0^{\mathrm{aE}}$ & $0^{\mathrm{aC}}$ & $0^{\mathrm{aD}}$ & $0^{\mathrm{aD}}$ \\
\hline Typhlodromalus aripo & $2^{\mathrm{aCD}}$ & $1^{\mathrm{aBC}}$ & $4^{\mathrm{aC}}$ & $3^{\mathrm{aD}}$ & $4^{\mathrm{aCD}}$ & $4^{\mathrm{aC}}$ & $1^{\mathrm{aCD}}$ & $3^{\mathrm{aCD}}$ \\
\hline
\end{tabular}

*Numbers followed by the same lowercase letter in the row and upper case in the column do not differ by the Tukey test ( $5 \%$ probability). 
Table 3 - Faunal analysis of adult mites collected in blackberry orchard in the period Nov. 2015 - Oct 2016, in the municipality of Pelotas, RS.

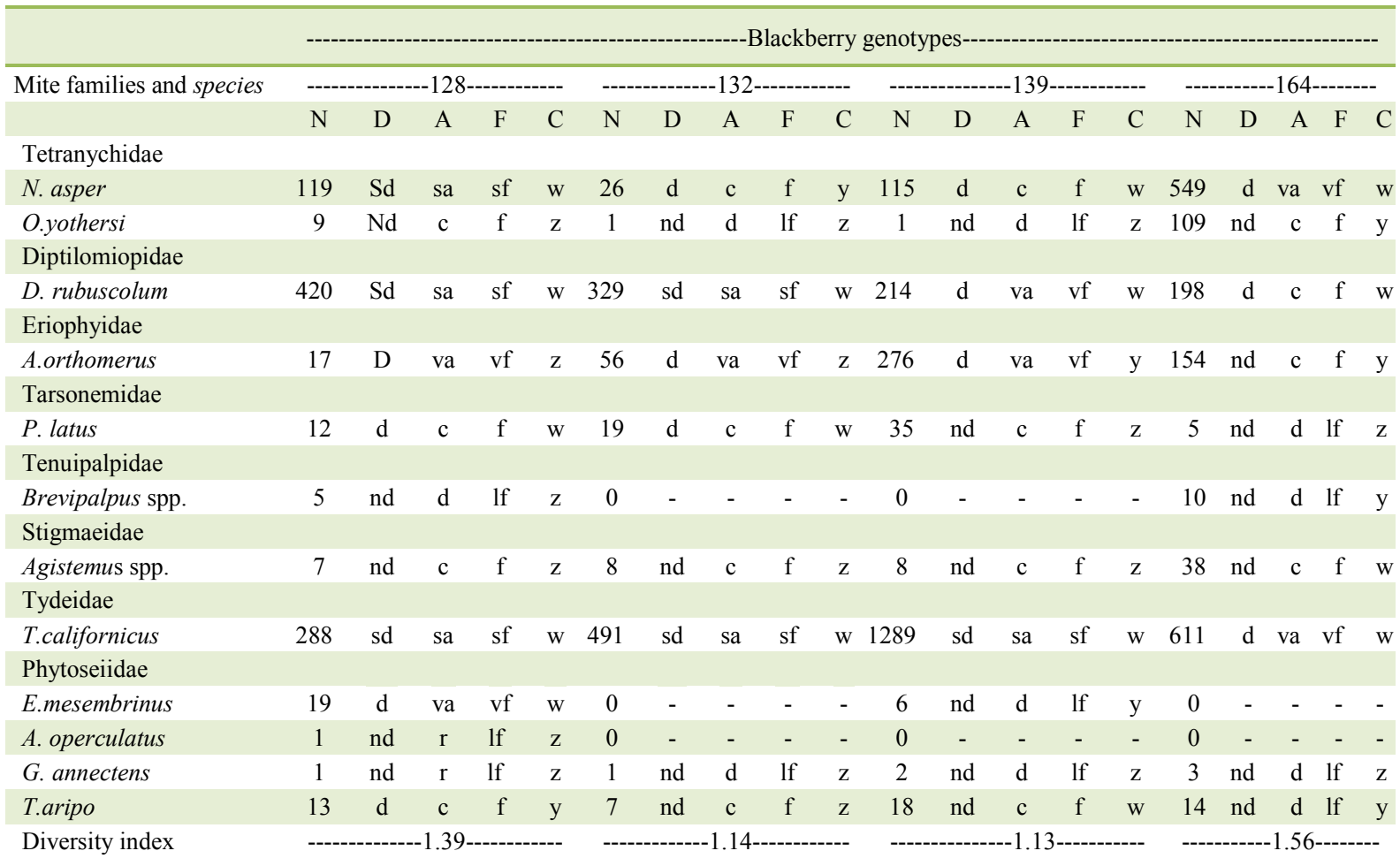

D: Dominance (sd: superdominant; d: dominant; nd: non-dominant); A: Abundance (sa: superabundant; va: very abundant; a: abundant; c: common; d: disperse; r: rare); F: Frequency (sf: super frequent; vf: very frequent; f: frequent; lf: little frequent); C: Constancy (w: constant; y: accessory; z: accidental); Dominance: Method of Sakagami and Larroca. N: total of individuals.

(MARCHETTI \& FERLA, 2011) and it was confirmed both to use herbivorous-induced volatile compounds to seek prey and discriminate between pubescent and glabrous cultivars in cassava culture (ONZO et al., 2012). This characteristic and mite morphology were used (MCMURTRY et al., 2013) to classify it as a generalist subtype III-a predator, which prefers pubescent leaves. In all blackberry genotypes analyzed in this study, the leaves have glabrous adaxial surface and pubescent abaxial surface, and only its type of indumentation varied. Thus, the idea that volatile compounds would also influence the behavior of these mites in the crop cannot be disregarded.

Amblyseius operculatus was absent in genotypes 132, 139, 164, and 198. However, its abundance was rare in genotypes 128 and 181 and "Tupy". According to MCMURTRY et al. (2013), this species is classified as generalist subtype III-b predators, which prefer glabrous leaves. All genotypes analyzed in this study present glabrous adaxial surface, and trichomes have a very low density on the abaxial surface, thus explaining the presence of this species in the culture. This phytoseiid species was not yet reported in the blackberry crop in RS. Occurrence of Amblyseius compositus (Denmark \& Muma, 1973), Amblyseius herbicolus (Chant, 1959), and Amblyseius neochiapensis (Lofego, Moraes \& McMurtry, 2000) in blackberry culture was reported by MARCHETTI \& FERLA (2011).

The phytoseiid Galendromus (G.) annectens, which was classified as common and frequent, was another species found in genotype 178 . It was reported to occur in blackberry plants (Rubus fruticosus; MARCHETTI \& FERLA, 2011) and wild mulberry along with other phytoseid (MCMURTRY $\&$ SHOW, 2012). The presence of Galendromus (G.) annectens, which was classified as a type-II predator 
Table 4 - Faunal analysis of adult mites collected in blackberry orchard in the period Nov 2015 - Oct 2016 , in the municipality of Pelotas, RS.

\begin{tabular}{|c|c|c|c|c|c|c|c|c|c|c|c|c|c|c|c|c|c|c|c|c|}
\hline \multirow[t]{2}{*}{ Mite families and species } & \multicolumn{5}{|c|}{---------------178------------- } & \multicolumn{5}{|c|}{-----------181------------ } & \multicolumn{5}{|c|}{-------------198------------ } & \multicolumn{5}{|c|}{--------------Tupy------------- } \\
\hline & $\mathrm{N}$ & $\mathrm{D}$ & A & $\mathrm{F}$ & $\mathrm{C}$ & $\mathrm{N}$ & $\mathrm{D}$ & A & $\mathrm{F}$ & $\mathrm{C}$ & $\mathrm{N}$ & $\mathrm{D}$ & A & $\mathrm{F}$ & $\mathrm{C}$ & $\mathrm{N}$ & $\mathrm{D}$ & A & $\mathrm{F}$ & $\mathrm{C}$ \\
\hline \multicolumn{21}{|l|}{ Tetranychidae } \\
\hline N. asper & 40 & sd & sa & sf & w & 165 & $d$ & va & vf & $\mathrm{w}$ & 362 & $\mathrm{~d}$ & $\mathrm{C}$ & $\mathrm{f}$ & $\mathrm{w}$ & 262 & $\mathrm{~d}$ & va & vf & $\mathrm{w}$ \\
\hline O.yothersi & 6 & nd & $\mathrm{c}$ & $\mathrm{f}$ & z & 3 & nd & $\mathrm{r}$ & lf & Z & 12 & nd & $\mathrm{D}$ & lf & $\mathrm{y}$ & 70 & nd & $\mathrm{c}$ & f & $\mathrm{w}$ \\
\hline \multicolumn{21}{|l|}{ Diptilomiopidae } \\
\hline D. rubuscolum & 161 & $\mathrm{Sd}$ & sa & sf & w & 146 & d & va & vf & $\mathrm{w}$ & 315 & $\mathrm{~d}$ & $\mathrm{C}$ & f & $\mathrm{w}$ & 81 & nd & $\mathrm{c}$ & $\mathrm{f}$ & $\mathrm{w}$ \\
\hline \multicolumn{21}{|l|}{ Eriophyidae } \\
\hline A.orthomerus & 101 & $\mathrm{Sd}$ & $\mathrm{sa}$ & sf & y & 121 & $\mathrm{~d}$ & $\mathrm{c}$ & $\mathrm{f}$ & $\mathrm{z}$ & 163 & nd & $\mathrm{C}$ & f & $\mathrm{z}$ & 316 & $\mathrm{~d}$ & va & $\mathrm{vf}$ & $\mathrm{y}$ \\
\hline \multicolumn{21}{|l|}{ Tarsonemidae } \\
\hline P. latus & 0 & - & - & - & - & 245 & d & va & vf & $\mathrm{z}$ & 687 & d & $\mathrm{Va}$ & vf & $\mathrm{z}$ & 2 & nd & $\mathrm{r}$ & If & z \\
\hline \multicolumn{21}{|l|}{ Tenuipalpidae } \\
\hline Brevipalpus spp. & 0 & - & - & - & - & 0 & - & - & - & - & 3 & nd & $\mathrm{R}$ & lf & $\mathrm{z}$ & 0 & - & - & - & - \\
\hline \multicolumn{21}{|l|}{ Stigmaeidae } \\
\hline Agistemus spp. & 10 & d & $\mathrm{c}$ & $\mathrm{f}$ & $\mathrm{y}$ & 34 & nd & $\mathrm{c}$ & f & $\mathrm{w}$ & 10 & nd & $\mathrm{R}$ & If & $\mathrm{w}$ & 52 & nd & $\mathrm{c}$ & f & $\mathrm{w}$ \\
\hline \multicolumn{21}{|l|}{ Tydeidae } \\
\hline T.californicus & 1235 & sd & $\mathrm{sa}$ & sf & w & 103 & d & $\mathrm{c}$ & f & $\mathrm{W}$ & 539 & d & $\mathrm{Va}$ & vf & $\mathrm{w}$ & 339 & d & va & vf & $\mathrm{w}$ \\
\hline \multicolumn{21}{|l|}{ Phytoseiidae } \\
\hline E.mesembrinus & 3 & nd & c & $\mathrm{f}$ & $\mathrm{z}$ & 1 & nd & $r$ & lf & $\mathrm{z}$ & 0 & - & - & - & - & 4 & nd & d & If & $\mathrm{z}$ \\
\hline A. operculatus & 1 & nd & d & lf & $\mathrm{z}$ & 2 & nd & $\mathrm{r}$ & If & $\mathrm{z}$ & 0 & - & - & - & - & 1 & nd & $\mathrm{r}$ & If & $\mathrm{z}$ \\
\hline G.annectens & 2 & nd & $\mathrm{c}$ & $\mathrm{f}$ & $\mathrm{z}$ & 1 & nd & $\mathrm{r}$ & If & $\mathrm{z}$ & 0 & - & - & - & - & 0 & - & - & - & - \\
\hline T.aripo & 20 & d & va & $\mathrm{vf}$ & y & 20 & nd & $\mathrm{d}$ & If & y & 4 & nd & $\mathrm{R}$ & If & $\mathrm{z}$ & 12 & nd & $d$ & If & w \\
\hline
\end{tabular}

D: Dominance (sd: superdominant; d: dominant; nd: non-dominant), A: Abundance (sa: superabundant; va: very abundant; a: abundant; c: common; d: disperse; r: rare), F: Frequency (sf: super frequent; vf: very frequent; f: frequent; lf: little frequent), C: Constancy (w: constant; y: accessory; z: accidental); Dominance: Method of Sakagami and Larroca. N: total of individuals.

(MCMURTRY et al., 2013), is probably linked to the presence of $O$. yothersi, which was also reported in the present study.

Agistemus spp. (Sumers, 1960) was classified as common and frequent in almost all (128, 132, 139, 164, 178, and 181) genotypes and "Tupy". Agistemus brasiliensis was reported in the Caingangue blackberry cultivar (MARCHETTI \& FERLA, 2011) and cited as a potential predator of the mite vector of citrus leprosis (MATIOLI \& OLIVEIRA, 2007).

Diptacus rubuscolum and T. californicus reached maximum classification values in genotype 132, as superdominant, superabundant, super frequent, and constant, without significant presence of predators. Acalitus orthomerus reached high faunal rates in fruits of genotypes 128, 132, and 139, as well as of genotype 178, and this was its first record in Brazil. This deserves more attention due to the potential damage of blackberry because it was reported to cause blisters and warts as a result of its large-scale feeding from buds. In addition, high infestation by $A$. orthomerus resulted in galls that do not allow budding (BAKER et al., 1996); although, mite-associated symptom was not observed in plants during the study period. It should be noted that symptoms of mite attack were observed outside the sampling period, but such symptoms corresponded to those reported for $A$. essigi, i.e., those that cause the so-called "redberry" symptom of mulberry (KEIFER et al., 1982; BAKER et al., 1996; DAVIES et al., 2001a). In Portugal, this mite is known as the "redberry mite" (FERREIRA \& PINA, 2012).

Thus, they are not enough to confirm and consider that it is a pest, compared to other mites in other cultures, despite a relatively high number of eriophid mites was found.

In relation to genotype 139, T. californicus was the predominant mite species. Furthermore, 
observations during evaluations indicated that the presence of trichomes and domatias would result in an important place for these mites to refuge. These same characteristics could also have favored the occurrence of $T$. californicus in all genotypes, as they all have trichomes and domatias in their leaves (Table 5). Tydeus californicus was reported by UECKERMANN \& GROUT (2007) and occurs as a prey for mite predators of citrus in South Africa. FLESCHNER \& ARAKAWA (1952) reported the occurrence of this same species on the abaxial surface of leaves in citrus and avocado trees and classified it as phytophagous mite; although, apparent symptoms of damage were not observed. In RS State, T. californicus was reported in association with grapevine (Vitis vinifera) culture (SILVA et al., 2014b). They offered a diet with and without pollen from Typha angustifolia L. (Typhaceae) to T. californicus and concluded that only leaf is not enough for them to complete their development; and pollen is therefore, an indispensable part of their diet (SILVA et al., 2014a).

Tydeid mites have a worldwide distribution and they can feed on plants,; although, they are recognized as predators of small insects and other mites and their eggs. Thus, T. californicus is a predator of the Aceria sheldoni (Ewing, 1937) citrus bud mite in southern California, USA (BAKER \& WHARTON, 1952). Tydeus gloveri Ashmead and Tydeus coccophagus Ewing were reported as predators of insects and their eggs (MCGREGOR, 1932).
Several foods were offered to two species of tydeid mites and aimed to know the existing nutritional phytophagous relationship. The importance of honeydew in the nutrition of both Lorryia ferulus Baker and Tydeus bakeri was the greatest revelation, because developing complete colonies was then possible. Tetranychus telarius mite eggs showed to be a good nutrient for L. ferulus but not for T. bakeri, which has never been observed in the field in association with mite eggs. The eriophid mites showed no nutritional importance, and the tetranychid Panonychus ulmi (Koch) also showed no positive result for any of both tydeid mites (BRICKHILL, 1958).

Another study suggested that tydeid mites are fungivorous. DUSO et al., (2005) evidenced this fact in Tydeus caudatus (Dugés) through the correlation between this mite and disseminated mildew in the commercial vineyard vegetation, because mite populations on symptomatic leaves were larger than those on asymptomatic leaves. This fact was also confirmed by MELIDOSSIAN et al. (2005), who reported that Orthotydeus lambi (Baker, 1970) can suppress fruit powdery mildew by reducing the inoculum in leaf infections.

Regarding pepper, morphology of the plant and distribution of trichomes influence mite development (MATOS et al., 2009). In all genotypes, blackberry leaves presented trichomes on the abaxial surface at very low density (Table 5). The occurrence of P. latus in blackberries with genotypes 181 and 198 could be related to other causes, as well as specific morphological and chemical causes that are attractive

Table 5 - Morphological characteristics on the adaxial (ADS) and abaxial (ABS) surfaces of leaves from black berry with different genotypes and Tupy cultivar.

\begin{tabular}{|c|c|c|c|c|c|c|c|c|c|c|c|c|c|c|c|}
\hline Gen. & ADS & ABS & $\mathrm{TI}^{*}$ & $\mathrm{DTL}^{*}$ & $\mathrm{TTL}^{*}$ & ADS & ABS & ADS & ABS & ADS & ABS & ADS & ABS & $\mathrm{DL}^{*}$ & $\mathrm{TD}^{*}$ \\
\hline & \multicolumn{3}{|c|}{------TL----- } & & & \multicolumn{2}{|c|}{----TNP----- } & \multicolumn{2}{|c|}{-----TTNP----- } & \multicolumn{2}{|c|}{-------TNS------ } & \multicolumn{2}{|c|}{------TTNS----- } & & \\
\hline 128 & A & $\mathrm{P}$ & $\mathrm{Pb}$ & Vl & $\mathrm{Sm}$ & $\mathrm{P}$ & $\mathrm{P}$ & $\mathrm{Sm}$ & $\mathrm{Sm}$ & A & $\mathrm{P}$ & - & $\mathrm{Sm}$ & $\mathrm{P}$ & $\mathrm{Tt}$ \\
\hline 132 & A & $\mathrm{P}$ & $\mathrm{Pb}$ & V1 & $\mathrm{Sm}$ & $\mathrm{P}$ & $\mathrm{P}$ & $\mathrm{Sm}$ & $\mathrm{Sm}$ & A & $\mathrm{P}$ & - & $\mathrm{Sm}$ & $\mathrm{P}$ & $\mathrm{Tt}$ \\
\hline 139 & A & $\mathrm{P}$ & Pl & V1 & $\mathrm{Sm}$ & $\mathrm{P}$ & $\mathrm{P}$ & $\mathrm{Sm}$ & $\mathrm{Sm}$ & A & $\mathrm{P}$ & - & $\mathrm{Sm}$ & $\mathrm{P}$ & $\mathrm{Tt}$ \\
\hline 164 & A & $\mathrm{P}$ & $\mathrm{Pl}$ & V1 & $\mathrm{Sm}$ & $\mathrm{P}$ & $\mathrm{P}$ & $\mathrm{Sm}$ & $\mathrm{Sm}$ & $\mathrm{P}$ & $\mathrm{P}$ & $\mathrm{Sm}$ & $\mathrm{Sm}$ & $\mathrm{P}$ & $\mathrm{Tt}$ \\
\hline 181 & A & $\mathrm{P}$ & $\mathrm{Pl}$ & $\mathrm{V} 1$ & $\mathrm{Sm}$ & $\mathrm{P}$ & $\mathrm{P}$ & $\mathrm{Sm}$ & $\mathrm{Sm}$ & A & $\mathrm{P}$ & - & $\mathrm{Sm}$ & $\mathrm{P}$ & $\mathrm{Tt}$ \\
\hline 178 & A & $\mathrm{P}$ & $\mathrm{Pb}$ & V1 & $\mathrm{Sm}$ & $\mathrm{P}$ & $\mathrm{P}$ & $\mathrm{Sm}$ & $\mathrm{Sm}$ & A & $\mathrm{P}$ & - & $\mathrm{Sm}$ & $\mathrm{P}$ & $\mathrm{Tt}$ \\
\hline 198 & A & $\mathrm{P}$ & $\mathrm{Pl}$ & $\mathrm{V} 1$ & $\mathrm{Sm}$ & $\mathrm{P}$ & $\mathrm{P}$ & $\mathrm{Sm}$ & $\mathrm{Sm}$ & A & $\mathrm{P}$ & - & $\mathrm{Sm}$ & $\mathrm{P}$ & $\mathrm{Tt}$ \\
\hline Tupy & A & $\mathrm{P}$ & $\mathrm{Pl}$ & $\mathrm{Vl}$ & $\mathrm{Sm}$ & $\mathrm{P}$ & $\mathrm{P}$ & $\mathrm{Sm}$ & $\mathrm{Sm}$ & A & $\mathrm{P}$ & - & $\mathrm{Sm}$ & $\mathrm{P}$ & $\mathrm{Tt}$ \\
\hline
\end{tabular}

Trichomes (TL), trichome density (DTL), and domatia (DL) on leaves, and trichomes in the main (NPT) and secondary (TNS) veins. Types of: indument (TI), trichomes [in leaves (TTL) and main (TTNP) and secondary (TTNS) veins], and domatias (TD).

*Abaxial surface; A: absence; P: Presence; Pilosity: (Pl: Pilous; Pb: Pubescent); Density, Types of trichomes and domatia when compared between blackberry genotypes: (Vl: Very low; Sm: Simple; Tt: Tuft of trichomes). 
or favor the species. In blackberry genotype 164, only the $N$. asper mite species was predominant. In blackberry genotype $181, D$. rubuscolum mite, in addition to the tetraniquid $N$. asper mite, was classified as dominant, very abundant, very frequent, and constant during the evaluation period. In blackberry genotypes 181 and 198, the tarsonemid $P$. latus mite was classified as dominant, very abundant, and very frequent. Although, this is the first report on its occurrence in blackberry in Brazil, it is considered a cosmopolitan species. VINCENT et al. (2010) reported the occurrence of the white mite in organic blackberry production causing the ripple symptom in the leaves. It was identified in vine crops (Bento Gonçalves, RS), occurring mainly in new vine leaves after green pruning (JOHANN et al., 2009). The white mite was found associated with the peach crop (Embrapa Clima Temperado; Pelotas, RS), occurring with higher population density in the JanuaryMay period, mainly after harvesting (ZANARDI et al., 2013). Its highest populational density occurs in early summer, especially in years with more rainfall and increased humidity (VIEIRA et al., 2004). These facts could elucidate its occurrence in mulberry trees, taking into account that dispersion of tarsonemid mites occurs by movement of adult forms to regions of growth of the same plant, contact between plant leaves, wind, and even foretically, as observed in P. latus mites on whiteflies (MORAES \& FLECHTMANN, 2008; ZANARDI et al., 2013).

In "Tupy", T. californicus and $A$. asper were classified as dominant, very abundant, very frequent, and constant; whereas, A. orthomerus was present in less than $50 \%$ of the samples. However, this is important for the symptoms they could cause on fruits.

In the study of blackberry genotypes, the values for the diversity index $(\mathrm{H})$ of mites varied in the range $0,83-1,79$. The maximum value for $\mathrm{H}$ was reached in genotype 181 (Table 4). MARCHETTI \& FERLA (2011) studied the diversity and fluctuation of mite population in blackberry cultivars and obtained a variable diversity index in the Caingangue (0.42) and Tupy (1.29) cultivars.

\section{CONCLUSION}

Twelve mite species are distributed in eight families in the blackberry orchard (Municipality of Pelotas, RS). The phytophagous $N$. asper and $D$. rubuscolum are predominant in blackberry genotypes 164 and 128, respectively. Therefore, future studies should focus on the characterization of damage caused by these mites.

\section{ACKNOWLEDGEMENTS}

To the $\mathrm{PhD}$ researchers at Embrapa Clima Temperado, Maria do Carmo B Raseira, for her help during sampling, Gustavo Heiden, for his help in the morphological description of the blackberry genotypes studied, and Gilberto José de Moraes, Carlos HW Flechtmann (Escola Superior de Agricultura Luiz de Queiroz (ESALQ)/Universidade de São Paulo (USP)), and Peterson R. Demite, for their help in identifying some mites.

\section{DECLARATION OF CONFLICTING INTERESTS}

The authors declare no conflict of interest. The founding sponsors had no role in the design of the study; in the collection, analyses, or interpretation of data; in the writing of the manuscript, and in the decision to publish the results.

\section{AUTHORS' CONTRIBUTIONS}

All authors contributed equally for the conception and writing of the manuscript. All authors critically revised the manuscript and approved of the final version.

\section{REFERENCES}

ANTUNES, L. E. C. et al. Fenologia e produção de cultivares de amoreira-pretaemsistemaagroecológico.CiênciaRural,SantaMaria, v.40, n.9, p.1929-1933, 2010. Available from: <http://www.scielo.br/ scielo.php?script $=$ sci_arttext\&pid $=$ S0103-84782010000900012>. Accessed: Jun. 21, 2017. doi: 10.1590/S0103-84782010000900012.

ANTUNES, L. E. C. et al. Blackberry production in Brazil. Revista Brasileira de Fruticultura, Jaboticabal, v.36, n.1, p.100-111, 2014. Available from: <http://www.scielo.br/scielo. php?script $=$ sci_arttext\&pid=S0100-29452014000100012>. Accessed: Jun. 22, 2017. doi: 10.1590/0100-2945-450/13.

BAKER, E. W.; WHARTON, G. W. An Introduction to Acarology. New York: The Macmillan Company. 1952. 490p. Available from: $<$ https://archive.org/stream/introductiontoac00bake\#page/n0>. Accessed: Jul. 23, 2017.

BAKER, E.W. et al. Eriophyoid mites of the United States. Michigan : Indira Publishing House, 1996. 394p.

BEENTJE, H. J.The Kew Plant Glossary: An Illustrated Dictionary of Plant Terms. ReinoUnido: Kew Publishing, 2016. 184p.

BRICKHILL, C.D. Biological studies of two species of tydeid mites from California. Hilgardia, v.27, n.20, p.601-622, 1958. Available from: <http://hilgardia.ucanr.edu/fileaccess. cfm?article $=152474 \& p=$ LNIZKC $>$. Accessed: Jul. 15, 2018. doi: 10.3733/hilg.v27n20p601.

DAVIES, J. T. et al. Dispersal of Acalitus essigi to blackberry (Rubus fruticosus agg.)frui. Entomologia Experimentalis et Applicata, v.101, p.19-23, 2001a. Available from: <http://onlinelibrary.wiley. com/doi/10.1046/j.1570-7458.2001.00886.x/full>. Accessed: Jul. 16, 2017. doi: 10.1046/j.1570-7458.2001.00886.x.

DAVIES, J. T. et al. Intraplant distribution of Acalitus essigi (Acari: Eriophyoidea) on blackberries (Rubus fruticosus agg.). 
Experimental \& Applied Acarology, Amsterdam, v.25, n.8, p.625-639, 2001b. Available from: <https://link.springer.com/art icle/10.1023/A:1016179817089>. Accessed: Jun. 20, 2017. doi: 10.1023/A:1016179817089.

MORAES, G.J.; FLECHTMANN, C.H.W. Manual de Acarologia: Acarologia básica \& ácaros de plantas cultivadas no Brasil. Ribeirão Preto: Holos Editora, 2008. 308p.

DUSO, C. et al. Grape downy mildew spread and mite seasonal abundance in vineyards: effects on Tydeus caudatus and its predators. Biological Control, v.32, p.143-154, 2005. Available from: $<$ https:// www.sciencedirect.com/science/article/pii/S104996440400177X>. Accessed: Jul. 23, 2018. doi: 10.1016/j.biocontrol.2004.09.004.

FERREIRA, M. A.; PINA, S. Ácaro-da-vaga-vermelha Acalitus essigi (Hassan). Coleção Técnico-Científica, Odemira, Portugal: INIAV / EUBerry, 2012. 18 p.

FLESCHNER, C. A.; ARAKAWA, K. Y. The mite Tydeus californicus on citrus and avocado leaves. Journal of Economic Entomology, Annapolis, v.45, n.6, p.1952.

GONÇALVES, E. G; LORENZI, H. Morfologia Vegetal. São Paulo: Instituto Plantarum de Estudos da Flora, 2007. 416p.

JOHANN, L. et al. Acarofauna (Acari) associada à videira (Vitisvinifera L.) no Estado do Rio Grande do Sul. Biociências, Porto Alegre, v.17, p.1-19. 2009. Available from: <https:// s3.amazonaws.com/academia.edu.documents/38362691/4756. pdf?AWSAccessKeyId=AKIAIWOWYYGZ2Y53UL3A\&Ex pires $=1520186668 \&$ Signature $=k P m j W n r Z Z M a k y D w B y e w g f$ uUmq5w\%3D\&response-content-disposition=inline $\% 3 \mathrm{~B} \% 20$ filename\%3DAcarofauna_Acari_associada_a_videira_Vit.pdf $>$. Accessed: Mar. 04, 2018.

KEIFER, H. H. et al. An illustrated guide to plant abnormalities caused by eriophyid mites in North America. United States Department of Agriculture. Agriculture handbook, n.573, p.177, 1982.

MARCHETTI, M; FERLA, N. J. Diversidade e flutuação populacional de ácaros (Acari) em amora-preta (Rubus fruticosus, Rosaceae) no estado do Rio Grande do Sul, Brasil. Iheringa, Porto Alegre, v.101, n.1-2, p.43- 48. 2011. Available from: <http://www.scielo.br/pdf/isz v101n1-2/v101n1-2a05.pdf>. Accessed: Jun. 22, 2017.

MATIOLI, A. L.; OLIVEIRA, C. A. L. Biologia de Agistemus brasiliensis Matioli, Ueckermann \& Oliveira (Acari: Stigmaeidae) e sua potencialidade de predação sobre Brevipalpus phoenicis (Geijskes) (Acari: Tenuipalpidae). Neotropical Entomology, Londrina, v.36, n.4, p.577-582, 2007. Available from: <http:// www.scielo.br/scielo.php?script=sci arttext\&pid=S1519 566X2007000400016>. Accessed: Jun. 21, 2017. doi: 10.1590/ S1519-566X2007000400016.

MATOS, C. H. C. et al. Os Tricomas de Capsicum spp. interferem nos aspectos biológicos do ácaro-branco Polyphagotarsonemus latus Banks (Acari: Tarsonemidae)? Neotropical Entomology, Londrina, v.38, n.5, p.1-6, 2009. Available from: <http:// www.scielo.br/scielo.php?script $=$ sci_arttext $\&$ pid $=$ S1519 566X2009000500005>. Accessed: Jun. 21, 2017. doi: 10.1590/ S1519-566X2009000500005.

MCGREGOR, E. A. The ubiquitous mite, a new species on citrus. Proceedings of the Entomological Society of Washington, v.34, n.4, p.60-61, 1932. Available from: <https://www. biodiversitylibrary.org/page/16144288\#page/342/mode/1up> . Accessed: Jul. 23, 2018

MCMURTRY, J. A.; SHOW, E. D. Phytoseiidae on blackberry in Central California. Systematic \& Applied Acarology, Londres, v.17, n.4, p.384-387, 2012. Available from: <http://www.bioone. org/doi/abs/10.11158/saa.17.4.6>. Accessed: Jun. 21, 2017. doi: 10.11158/saa.17.4.6>

MCMURTRY, J. A. et al. Revision of the lifestyles of phytoseiid mites (Acari: Phytoseiidae) and implications for biological control strategies. Systematic \& Applied Acarology, Londres, v.18, n.4, p.297-320, 2013. Available from: <https://www.biotaxa.org/saa/ article/view/saa.18.4.1/0>. Accessed: Jun. 21, 2017. doi: 10.11158/ saa.18.4.1.

MELIDOSSIAN, H. S. et al. Suppression of grapevine powdery mildew by a mycophagousmite. Plant Disease, v.89, n.12, p.13311338, 2005. Available from: <https://apsjournals.apsnet.org/doi/ abs/10.1094/PD-89-1331>. Accessed: Jul. 23, 2017.

MORAES, R. C. B.; et al. Software para análise estatística ANAFAU. In: SIMPÓSIO DE CONTROLE BIOLÓGICO VIII, 2003, São Pedro, SP. Resumos... Piracicaba: ESALQ/USP, 2003, p.195.

NAVA, D. E.; et al. 2007. Agência Embrapa de Informação Tecnológica. Available from: <http:// www.agencia.cnptia.embrapa.br/gestor/amora/arvore/ CONT000ggtku91902wx5ok05vadr139ze31r.html>. Accessed: Apr. 13, 2017.

ONZO, A. et al. The predatory mite Typhlodromalus aripoprefers green-mite induced plant odours from pubescent cassava varieties. Experimental and Applied Acarology, Amsterdam, v.58, n.4 p.359-370, 2012. Available from: <https://www.ncbi.nlm.nih. gov/pmc/articles/PMC3487005/>. Accessed: Jun. 21, 2017. doi: 10.1007/s10493-012-9595-0.

PAGOT, E.; et al. Cultivo da amora-preta. Bento Gonçalves: Embrapa Uva e Vinhos, 2007. 11p. (Circular Técnica, 75).

PINA, S. et al. Os ácaros na cultura da amora em estufa e infestantes. IV Colóquio Nacional da Produção de Pequenos Frutos, Actas Portuguesas de Horticultura. Odemira, n.20, p.69-76, 2012.

RASEIRA, M. C. B.; FRANZON, R. C. Melhoramento genético e cultivares de amora-preta e mirtilo. Informe Agropecuário, Belo Horizonte, v.33, n.268, p.11-20, 2012.

SILVA, G. L. da et al. Life cycle of Tydeus californicus (Acari: Tydeidae) on leaves of Inga marginata with and without pollen of Typha angustifolia under laboratory conditions. International Journal of Acarology, Abingdon, v.40, p.1-4, 2014a.

SILVA, G. L. da et al. Tydeid and triophtydeid mites (Acari: Tydeoidea) associated with grapevine (Vitaceae: Vitis spp.) in Brazil, with the descriptions of species of Prelorryia (André, 1980) and Tydeus Koch, 1835. Zootaxa, Auckland, v.3814, n.4, p.495$511,2014 \mathrm{~b}$

TRINIDAD, C.T.O. et al. Eriophyoid mites associated with the blackberry in Brazil-a new species in the genus Diptacus Keifer 1951 (Diptilomiopidae) and first report and supplementary description of Acalitus orthomerus (Keifer, 1951) (Eriophyidae). Systematic \& Applied Acarology, Auckland, v.23, n.6, p.1199-1216, 2018. 
UECKERMANN, E. A.; GROUT, T. G. Tydeoid mites (Acari: Tydeidae, Edbakerellidae, Iolinidae) occurring on citrus in Southern Africa. Journal of Natural History, Londres, v.41, n.3741, p.2351-2378, 2007.

VIEIRA, M. R. et al. Efeito do cultivo do mamoeiro (Carica papaya L.) em ambiente protegido sobre a ocorrência de ácaros fitófagos e moscas-brancas. Revista Brasileira de Fruticultura, Jaboticabal, v.26, n.3, p.441-445, 2004. Available from: <http://www.scielo.br/ pdf/rbf/v26n3/23141.pdf $>$. Accessed: Mar. 05, 2018.
VINCENT, C. I. et al. Broad mite on primocane-fruiting blackberry in organic production in Arkansas. Hort Technology, Alexandria, v.20, n.4, p.718-723, 2010. Available from: <http:// horttech.ashspublications.org/content/20/4/718.full>. Accessed: Jun. 22, 2017.

ZANARDI, O. Z. et al. Flutuação Populacional dos Principais ácaros em Pessegueiro nos Sistemas de Cultivos Protegidos e Convencional. Comunicado Técnico, Pelotas, p.1-6, 2013. 